\title{
AKIBAT HUKUM JUAL BELI HAK ATAS TANAH YANG BELUM DIDAFTARKAN
}

\author{
THE LEGAL IMPACTS OF PURCHASING \\ UNREGISTERED LAND RIGHTS
}

\author{
Baiq Henni Paramita Rosandi \\ Magister Kenotariatan Universitas Mataram \\ Email: baiqhenniparamitarosandi@yahoo.com \\ Naskah diterima : 20/11/2016; revisi : 21/12/2016; disetujui : 30/12/2016
}

\begin{abstract}
The Purposes of this research is to analyse how should the transfer of land rights because of purchasing unregistered land, the legal impact of purchasing unregistered land, and legal protection towards the buyer of unregistered land. Base on the Article 19 of the Acts Number 5 Year 1960 and Government Regulation Number 24 Year 1977, that the transfer of land right in purchasing is by registration according to the determined procedure.. The legal impact of purchasing unregistered land is legal if it fulfilled the real, clear, and cash requirements in its application. Then in Article 19 of the Acts Number 5 Year 1960 is not applied rigidly in according to the Decision Number 19/Pdt.G/2015/PN.MGG, it is assume legal and protected if it fulfilled the real, clear, and cash requirements. The legal protection on the buyer of land rights that not registered if it get with a good faith, and get repressive legal protection.
\end{abstract}

Keywords : rights of land, purchase, registration of land

Abstrak

Tujuan penelitian ini adalah untuk menganalisis bagaimana seharusnya peralihan hak atas tanah karena jual beli terhadap tanah yang belum didaftarkan, akibat hukum yang ditimbulkan jual beli hak atas tanah terhadap tanah yang belum didaftarkan dan perlindungan hukum terhadap pembeli hak atas tanah yang belum didaftarkan. Berdasarkan ketentuan Pasal 19 UU No. 5 Tahun 1960 dan Peraturan Pemerintah No. 24 Tahun 1977 seharusnya peralihan hak atas tanah karena jual beli dilakukan pendaftaran sesuai dengan prosedur yang telah ditentukan. Akibat hukum peralihan hak atas tanah karena jual beli terhadap tanah yang belum didaftarkan adalah sah apabila telah memenuhi syarat riil, terang dan tunai dalam praktek Pasal 19 UU No. 5 Tahun 1960 tidak diterapkan secara kaku dengan berdasarkan Putusan Nomor 19/Pdt.G/2015/PN.MGG dianggap sah dan berharga serta dilindungi apabila telah memenuhi syarat rill, terang dan tunai. Perlindungan hukum terhadap pembeli hak atas tanah karena jual beli terhadap tanah yang belum didaftarkan apabila yang memperolehnya dengan itikad baik tetap mendapatkan perlindungan berupa perlindungan hukum represif.

\section{Kata Kunci: Hak atas tanah, jual beli, pendaftaran tanah}

\section{PENDAHULUAN}

Seiring berkembangnya zaman, yang pada awalnya tanah hanya digunakan dan/atau dimanfaatkan untuk tempat tinggal, karena selain bertambahnya jumlah manusia yang memerlukan tanah untuk tempat tinggal, juga kemajuan dan perkembangan ekonomi, sosial, budaya dan teknologi menghendaki pula tersedianya tanah yang banyak, umpamanya untuk perkebunan, peternakan, pabrik-pabrik, perkantoran, bahkan tempat hiburan dan jalan untuk sarana perhubungan.

Oleh karena dirasakanfungsi dan kedudukan tanah yang sangat penting dalam kehidupan manusia karena tanah merupakan 
sumber kesejahteraan, kemakmuran, dan kehidupan, sertakegunaan tanahyangbegitu strategi, mengakibatkan nilai tanah menjadi meningkat tinggi. Tanah merupakan sumber daya yang sudah sangat diperlukan saat ini, hal ini disebabkan meledaknya populasi pertumbuhan manusia yang tentunya membutuhkan lahan untuk tempat hidup yang bersifat primer. Sehingga mengakibatkan ketidakseimbangan antara persediaan tanah dengan kebutuhan akan tanah. Maka tidak heran jika tanah merupakan sumber konflik yang paling tinggi.

Dalam masyarakat, perolehan hak atas tanah lebih sering dilakukan dengan peralihan hak, yaitu dengan melalui jual beli. Menurut Boedi Harsono, "Dalam Hukum Adat perbuatan pemindahan hak (jual-beli, hibah, tukar menukar) merupakan perbuatan hukum yang bersifat tunai". Jual-beli dalam hukum tanah dengan pembayaran harganya pada saat yang bersamaan secara tunai. ${ }^{1}$

Kemudian menurut hukum (BW) Pasal 1457 disebutkan bahwa jual-beli tanah adalah suatu perjanjian dengan mana penjual mengikatkan dirinya (artinya berjanji) untuk menyerahkan hak atas tanah yang bersangkutan kepada pembeli yang mengikatkan dirinya untuk membayar kepada penjual harga yang telah disepakati nya. ${ }^{2}$ Adapun ketentuan yang diatur dalam seluruh Buku II KUH Perdata telah dicabut dan tidak berlaku lagi.

Sejak berlakunya Undang-Undang Nomor 5 Tahun 1960 tentang PokokPokok Agraria (UUPA), peralaihan hak atas tanah dapat dilakukan melalui jual beli yang dimaksudkan untuk memindahkan hak milik. Adapun yang dimaksud dengan peralihan hak atas tanah adalah perbuatan hukum pemindahan hak atas tanah yang dilakukan dengan sengaja supaya hak

\footnotetext{
${ }^{1}$ Harun Al-Rashid, Sekilas Tentang Jual-Beli Tanah (Berikut Peraturan-Peraturanya), Ghalia Indonesia, Jakarta, 1986, hlm. 51

${ }^{2}$ Ibid, hlm. 52
}

tersebut terlepas dari pemegang nya semula dan menjadi hak pihak lain. ${ }^{3}$

Dalam hal memerlukan tanah, dari ketentuan hukumnya tidak banyak yang mengetahui carabagaimana memperolehnya dan apa yang menjadi alat buktinya. Jika tanah yang bersangkutan berstatus hak milik maka akan mudah untuk diketahui bahwa tanah yang bersangkutan boleh dikuasai dan digunakan tanpa batas waktu.

Akan tetapi bagi seseorang yang akan membeli tanah, pengetahuan mengenai halhal tersebut, bagaimanapun pentingnya, belum cukup untuk sampai pada keputusan membeli tanah yang ditawarkan kepadanya. ${ }^{4}$ Hal yang paling utama ingin diperoleh yakni kepastian terlebih dahulu. Oleh karena terbatasnya jumlah tanah untuk dijadikan sebagai sumber penghasilan dan tempat tinggal, maka orang perlu untuk mendapatkan suatu jaminan akan kepastian hukum dan perlindungan hukum terhadap hak kepemilikan atas tanah yang mereka miliki. Semuanya itu diperlukan untuk mengamankan pembelian yang akan dilakukan dan mencegah timbulnya sengketa di kemudian hari.

Untuk itu, salah satu yang menjadi tujuan dari Undang-Undang Pokok Agraria (UUPA) adalah untuk memberikan kepastianhukumberkenaan denganhak-hak atas tanah yang dipegang oleh masyarakat. Bahwa, tujuan UUPA tidak lain untuk meletakkan dasar-dasar bagi penyusunan hukum agraria nasional yang merupakan alat untuk mencapai kemakmuran, kebahagiaan, dan keadilan bagi negara dan rakyat nya, juga untuk meletakkan dasardasar kesatuan dan kesederhanaan hukum pertanahan serta meletakkan dasar untuk

${ }^{3}$ Saleh Adiwinata, Pengertian Hukum Adat Menurut Undang-Undang Pokok Agraria, Alumni, Bandung, 1980, hlm. 21

${ }^{4}$ Budi Harsono (I), Hukum Agraria Indonesia: Sejarah Pembentukan Undang-Undang Pokok Agraria, Isi dan Pelaksanaannya, Edisi Revisi, Cetakan VIII, Djambatan, Jakarta, 1999, hlm. 70-71 
memberikan kepastian hukum mengenai hak-hak atas tanah bagi rakyat seluruhnya. ${ }^{5}$

Untuk menjamin kepastian hukum serta perlindungan hukum tersebut oleh pemerintah dalam kaitannya dengan peralihan hak atas tanah sebagaimana yang diamanatkan dalam ketentuan Pasal 19 ayat (1) Undang-Undang Nomor 5 Tahun 1960 tetang Pokok-Pokok Agraria atau yang lebih dikenal dengan UUPA diadakan pendaftaran tanah di seluruh wilayah Republik Indonesia menurut ketentuanketentuan yang diatur dengan peraturan pemerintah.

Pada Peraturan Pemerintah Nomor 24 Tahun 1997 tentang Pendaftaran Tanah ini yang dimaksud dengan pendaftaran tanah, sebagaimana disebut oleh Pasal 1 ayat (1), adalah sebagai berikut :

"Pendaftaran tanah adalah rangkaian kegiatan yang dilakukan oleh Pemerintah secara terus menerus, berkesinambungan dan teratur, meliputi pengumpulan, pengolahan, pembukuan, dan penyajian serta pemeliharaan data fisik dan data yuridis, dalam bentuk peta dan daftar, mengenai bidang-bidang tanah dan satuan-satuan rumah susun, termasuk pemberian surat tanda bukti haknya bagi bidang-bidang tanah yang sudah ada haknya dan hak milik atas satuan rumah susun serta hakhak tertentu yang membebaninya."

Undang-Undang nomor 5 Tahun 1960 tentang Pokok-pokok Agraria dan Peraturan Pemerintah Nomor 24 Tahun 1997 tentang pendaftaran tanah, untuk menjamin kepastian hukum diwajibkan untuk melakukan pendaftaran diseluruh wilayah Republik Indonesia terutama terkait dengan peralihan hak atas tanah karena jual beli terhadap tanah yang belum didaftarkan, namun dalam tataran aplikasi nya masih banyak terdapat peralihan hak atas tanah karena jual beli terhadap tanah yang belum didaftarkan.

\footnotetext{
${ }^{5}$ J. Kartini Soedjendro, Op. Cit, hlm. 66
}

Dalam hal ini dapat dikatakan bahwa jika ada keharusan yang merupakan kewajiban bagi masyarakat yang melakukan perbuatan hukum yakni jual beli hak atas tanah untuk didaftarkan maka seharusnya ada sanksi bagi masyarakat yang tidak mendaftarkan peralihan hak atas tanah terhadap tanah yang belum didaftarkan. Akan tetapi dalam ketentuan pasal 19 UUPA dan Peraturan Pemerintah Nomor 24 Tahun 1997 tentang pendaftaran tanah, tidak ditemukan adanya pasal yang mengatur mengenai sanksi dan/ atau akibat hukum yang ditimbulkan dari jual beli hak atas tanah yang belum didaftarkan.

Berdasarkan uraian di atas, maka muncul beragam isu hukum antara lain : 1). Bagaimana seharusnya peralihan hak atas tanah karena jual beli terhadap tanah yang belum didaftarkan?, 2). Bagaimana akibat hukum yang ditimbulkan jual beli hak atas tanah terhadap tanah yang belum didaftarkan? 3). Bagaimana perlindungan hukum terhadap pembeli hak atas tanah yang belum didaftarkan?.

Penelitian ini bertujuan untuk : 1) Untuk mengkaji dan menganalisis peralihan hak atas tanah karena jual beli terhadap tanah yang belum didaftarkan. 2) Untuk mengkaji dan menganalisis akibat hukum yang ditimbulkan jual beli hak atas tanah terhadap tanah yang belum didaftarkan. 3) Untuk mengkaji dan menganalisis perlindungan hukum terhadap pembeli hak atas tanah yang belum didaftarkan.

Penelitian ini dikategorikan sebagai penelitian normatif dengan menggunakan metode pendekatan perundang-undangan, pendekatan konseptual dan pendekatan kasus yang berpedoman pada literaturliteratur yang ada relevansinya dengan masalah yang diteliti. Dengan metode analisa preskriptif yaitu analisis bahan hukum yang dimaksudkan untuk memberikan argumentasi atas hasil penelitian yang telah dilakukannya. 


\section{PEMBAHASAN}

\section{A. Peralihan Hak Atas Tanah Karena Jual Beli Terhadap Tanah Yang Belum Didaftarkan}

Terkait dengan peralihan hak atas tanah karena jual beli terhadap tanah yang belum didaftarkan atau dengan kata lain tanah hak yang tidak bersertifikat dalam ketentuan Peraturan Pemerintah Nomor 24 Tahun 1997 tentang Pendaftaran Tanah tidak ditemukan pasal yang mengatur secara khusus mengenai peralihan hak atas tanah khususnya terhadap tanah yang belum didaftarkan. Melainkan dari ketentuan peralihan hak atas tanah dari Pasal 37 sampai dengan Pasal 40 Peraturan Pemerintah Nomor 24 Tahun 1997 tentang Pendaftaran Tanah, dimana hanya dalam Pasal 39 ayat (1) huruf b yang menyinggung mengenai bidang tanah yang belum terdaftar, akan tetapi dalam ketentuan Pasal 39 ayat (1) huruf b tersebut hanya saja mengatur tentang penolakan oleh Pejabat Pembuat Akta Tanah (PPAT) dalam hal untuk membuat akta, yang menegaskan apabila mengenai bidang tanah yang belum terdaftar, kepadanya tidak disampaikan :

1. Surat bukti hak sebagaimana dimaksud dalam Pasal 24 ayat (1) atau surat keterangan Kepala Desa/Kelurahan yang menyatakan bahwa yang bersangkutan menguasai bidang tanah tersebut sebagaimana dimaksud dalam Pasal 24 ayat (2); dan

2. Surat keterangan yang menyatakan bahwa bidang tanah yang bersangkutan belum bersertifikat dari Kantor Pertanahan, atau untuk tanah yang terletak di daerah yang jauh dari kedudukan Kantor Pertanahan, dari pemeganghakyangbersangkutandengan dikuatkan oleh Kepala Desa/Kelurahan.

Selanjutnya, termasuk dalam Peraturan Menteri Negara Agraria/kepala Badan Pertanahan Nasional Nomor 3 Tahun 1997 tentang Ketentuan Pelaksanaan Peraturan Pemerintah Nomor 24 Tahun 1997 tentang Pendaftaran Tanah belum juga diatur secara terperinci dan/atau khusus terkait dengan peralihan hak atas tanah karena jual beli terhadap tanah yang belum didaftarkan. Akan tetapi dalam ketentuan yang mengatur mengenai pendaftaran peralihan hak karena pemindahan hak sebagaimana diatur pada Pasal 103 sampai dengan Pasal 106, hanya pada Pasal 103 ayat (3) dan Pasal 106 yang membahas hal pemindahan hak atas tanah yang belum terdaftar, dan kedua Pasal tersebut masih mengatur secara umum mengenai peralihan hak atas tanah yang belum terdaftar.

Dapat disimpulkan bahwa dengan berdasarkan pada teori perlindungan hukum dengan mengacu pada ketentuan Pasal 3 huruf a dan Pasal 4 ayat (1) Peraturan Pemerintah Nomor 24 Tahun 1997 tentang Pendaftaran Tanah yang mengatur tentang tujuan dari pendaftaran tanah, yang mana pendaftaran tanah bertujuan untuk memberikan perlindungan hukum kepada pemegang hak atas suatu bidang tanah sehingga dengan mudah dapat membuktikan dirinya sebagai pemegang hak yang bersangkutan. Dan untuk memberikan perlindungan hukum sebagaimana dimaksud kepada pemegang hak yang bersangkutan diberikan sertifikat hak atas tanah.

Oleh karena itu, seharusnya peralihan hak atas tanah karena jual beli terhadap tanah yang belum didaftarkan dengan berdasarkan pada ketentuan Pasal 19 Undang-Undang Nomor 5 Tahun 1960 tentang Pokok-Pokok Agraria yang mengharuskan diadakan pendaftaran tanah di seluruh wilayah Republik Indonesia, maka peralihan hak atas tanah karena jual beli terhadap tanah yang belum didaftarkan harus didaftarkan. Yang mana peralihan hak atas tanah karena jual beli tersebut harus dibuktikan dengan akta yang dibuat oleh PPAT yang berwenang 
Baiq Henni Paramita Rosandi| Akibat Hukum Jual Beli Hak Atas Tanah Yang Belum Didaftarkan....

menurut ketentuan peraturan perundangundangan yang berlaku, sebagaimana yang diatur dalam Pasal 37 Peraturan Pemerintah Nomor 24 Tahun 1997 tentang Pendaftaran Tanah. Karena akta peralihan hak yg dibuat oleh PPAT merupakan dasar dan/atau alas hak untuk melakukan permohonan pendaftaran peralihan hak atas tanah. Apabila tidak didaftarkan serta perbuatan hukum yakni jual beli tersebut tidak dilakukan di hadapan PPAT, maka perbuatan hukum tersebut bukanlah jual beli yang mengakibatkan beralihnya hak atas tanah yang bersangkutan kepada pembeli atau pemegang hak baru. Sebagaimana yang ditegaskan dalam ketentuan Pasal 23 UUPA, yang menyebutkan bahwa hak milik demikian pula setiap peralihan harus didaftarkan menurut ketentuan-ketentuan yang dimaksud dalam Pasal 19. Pendaftaran tersebut merupakan alat pembuktian yang kuat mengenai hapus nya hak milik, serta sahnya peralihan dan pembebanan hak tersebut.

\section{B. Akibat Hukum Yang Ditimbulkan Jual Beli Hak Atas Tanah Terhadap Tanah Yang Belum Didaftarkan}

Perbuatan hukum yakni jual beli tanah tersebut sering kali dilakukan di bawah tangan, yang terkadang hanya dibuktikan dengan selembar kwitansi sebagai bukti telah terjadinya jual beli dan tidak sedikit masyarakat yang hanya memiliki bukti kepemilikan atas tanah. Sehingga mengakibatkan peralihan hak atas tanah karena jual beli tidak dapat didaftarkan sebagaimana yang diamanatkan dalam ketentuan Pasal 19 dan Pasal 23 UndangUndang Nomor 5 Tahun 1960 tentang Pokok-Pokok Agraria.

Dalam hal ini menimbulkan akibat hukum yaitu tidak terjadinya peralihan hak atas tanah dan/atau tidak sahnya peralihan hak atas tanah dan tidak adanya jaminan kepastian hukum serta perlindungan hukum. Sebagaimana yang ditegaskan dalam ketentuan pasal 23 ayat (2), yang berbunyi :

"pendaftaran termaksud dalam ayat (1) merupakan alat pembuktian yang kuat mengenai hapusnya hak milik serta sahnya peralihan dan pembebanan hak tersebut."

Untuk dapat memperoleh kepastian hukum, masyarakat dalam melakukan perbuatan hukum terkait dengan peralihan hak atas tanah yaitu jual beli, harus melakukan pendaftaran peralihan hak atas tanah. Oleh karena dalam hal jual beli tanah tidak dapat diselesaikan begitu saja oleh para pihak yang bersangkutan, akan tetapi agar jual beli tersebut sah menurut hukum maka sangat diperlukan campur tangan pejabat yang berwenang untuk menyelesaikannya serta segala peralihan hak milik atas tanah karena jual beli harus mengikuti ketentuan dan prosedur yang diatur dan atau diamanatkan oleh undang-undang yang berlaku. Maka setiap peralihan hak milik atas tanah karena jual beli harus didaftarkan baik yang sudah bersertifikat maupun yang belum didaftarkan, berdasarkan ketentuanketentuan yang dimaksud dalam Pasal 19 UUPA, sebagaimana yang telah diatur dalam Pasal 23 ayat (1) UUPA, yang mana dalam ketentuan Peraturan Pemerintah Nomor 24 Tahun 1997 tentang Pendaftaran Tanah Pasal 37 ayat (1) menyatakan bahwa peralihan hak atas tanah melalui jual beli hanya dapat didaftarkan jika dibuktikan dengan akta yang dibuat oleh PPAT yang berwenang menurut ketentuan peraturan perundang-undangan yang berlaku. Karena keharusan pendaftaran peralihan hak milik atas tanah sebagaimana yang dimaksud dalam Pasal 23 ayat (1) UUPA merupakan alat pembuktian yang kuat mengenai hapus nya hak milik serta sahnya peralihan dalam pembebanan hak tersebut, berdasarkan bunyi Pasal 23 ayat (2) UUPA.

Secara tegas juga diatur dalam Pasal 3 huruf a Peraturan Pemerintah Nomor 
24 tahun 1997 tentang Pendaftaran Tanah, bahwa adapun yang menjadi tujuan dari pendaftaran tanah yakni untuk memberikan kepastian hukum dan perlindungan hukum kepada pemegang hak atas suatu bidang tanah agar dengan mudah dapat membuktikan dirinya sebagai pemegang hak yang bersangkutan. Untuk memberikan kepastian serta perlindungan hukum sebagaimana dimaksud dalam Pasal 3 huruf a tersebut, kepada pemegang hak yang bersangkutan diberikan sertifikat hak atas tanah, sebagaimana yang diatur dalam Pasal 4 Peraturan Pemerintah Nomor 24 tahun 1997 tentang Pendaftaran Tanah.

Kepastian hukum yang dimaksud dalam kegiatan pendaftaran tanah di atas, antara lain : 6

1. Kepastian hukum mengenai orang atau badan yang menjadi pemegang hak (subjek hak);

2. Kepastian hukum mengena lokasi, batas, serta luas suatu bidang tanah hak (subjek hak); dan

3. Kepastian hukum mengenai haknya.

Dalam rangka jual beli dan pemindahan hak lainnya fungsi pendaftaran tanah adalah untuk : ${ }^{7}$

1. Memperkuat pembuktian, sebab pemindahan hak tersebut dicatat pada buku tanah dan sertifikat hak dicantumkan siapa pemegang haknya sekarang.

2. Memperluas pembuktian, karena dengan pendaftaran tanah jual belinya dapat diketahui oleh umum atau siap saja yang berkepentingan.

Akan tetapi apabila dilihat dari ketentuan peralihan hak atas tanah secara hukum adat dengan berdasarkan pada Pasal 5 Undang-

\footnotetext{
${ }^{6}$ Bachtiar Effendie, Pendaftaran Tanah di Indonesia dan Peraturan-peraturan Pelaksanaannya. Alumni. Bandung, 1980, hlm. 9-10

${ }^{7}$ Ibid, hlm. 10-11
}

undang Nomor 5 Tahun 1960 tentang PokokPokok Agraria, yang menyatakan bahwa hukum agraria berdasarkan pada hukum adat. Dalam hal jual beli tanah menurut hukum adat bersifat kontan atau "tunai". Pembayaran harga dan penyerahan haknya dilakukan pada saat yang bersamaan. Pada saat itu jual beli tersebut menurut hukum telah selesai. ${ }^{8}$

Biasanya jual beli tanah itu dilakukan di muka Kepala Adat (Desa), yang bukan hanya bertindak sebagai saksi tetapi dalam kedudukannya sebagai Kepala Adat (Desa) menanggung bahwa jual beli tersebut tidak melanggar hukum yang berlaku. ${ }^{9}$

Effendi Perangin berpendapat, bahwa dengan dilakukannya jual beli di muka Kepala Adat (Desa), jual beli itu menjadi "terang", bukan perbuatan hukum yang "gelap". Dengan demikian maka pembeli mendapat pengakuan dari masyarakat yang bersangkutan sebagai pemilik yang baru dan akan mendapat perlindungan hukum jika dikemudian hari ada gugatan terhadapnya dari pihak yang menganggap jual-beli tersebut tidak sah. ${ }^{10}$

Menurut Effendi Perangin bahwa UUPA tidak memberikan penjelasan mengenai apa yang dimaksudkan dengan jual beli tanah. Tetapi biarpun demikian mengingat bahwa hukum agrarian kita sekarang ini memakai system dan asa-asas hukum adat, maka pengertian jual beli tanah sekarang harus pula diartikan sebagai perbuatan hukum yang berupa penyerahan hak milik (penyerahan tanah untuk selama-lamanya) oleh penjual kepada pembeli, yang pada saat itu juga menyerahkan harganya kepada penjual. Yaitu menurut pengertian Hukum Adat. ${ }^{11}$

\footnotetext{
8 Effendi Perangin, Hukum Agraria Di Indonesia : Suatu Telaah Dari Sudut pandang Praktisi Hukum, Edisi 1, Cetakan 1, Rajawali, Jakarta, 1986, hlm. 16

${ }^{9}$ Ibid

${ }^{10}$ Ibid

${ }^{11}$ Ibid, hlm. 13
} 
Dalam masyarakat Hukum Adat jual beli tanah dilaksanakan secara terang dan tunai. Terang berarti perbuatan hukum jual beli tersebut benar-benar dilaksanakan di hadapan Kepala Adat atau Kepala Desa. Tunai, berarti adanya dua perbuatan yang dilaksanakan secara bersamaan, yaitu pemindahan hak atas tanah yang menjadi obyek jual beli dari penjual kepada pembeli dan pembayaran harga dari pembeli kepada penjual terjadi serentak dan secara bersamaan. ${ }^{12}$

Jual beli menurut hukum tanah nasional yang bersumber pada hukum adat, dimana apa yang dimaksud dengan jual beli bukan merupakan perbuatan hukum yang merupakan perjanjian obligatoir. Jual beli (tanah) dalam hukum adat merupakan perbuatan hukum pemindahan hak yang harus memenuhi tiga (3) sifat yaitu : ${ }^{13}$

1. Harus bersifat tunai, artinya harga yang disetujuibersamadibayarpenuhpadasaat dilakukan jual beli yang bersangkutan.

2. Harus bersifat terang, artinya pemindahan hak tersebut dilakukan di hadapan Pejabat Pembuat Akta Tanah yang berwenang atas obyek perbuatan hukum.

3. Bersifat riil atau nyata, artinya dengan ditandatangani akta pemindahan hak tersebut, maka akta tersebut menunjukkan secara nyata dan sebagai bukti dilakukan perbuatan hukum tersebut.

Akibat hukum peralihan hak atas karena jual beli terhadap tanah yang belum didaftarkan adalah sah menurut hukum apabila peralihan hak atas tanah karena jual beli terhadap tanah yang belum didaftarkan tersebut sudah memenuhi syarat materiil jual beli yaitu "terang dan "Tunai", dengan

\footnotetext{
${ }^{12}$ Ibid, hlm. 15

${ }^{13}$ Boedi Harsono (II), Hukum Agraria Indonesia, Sejarah Pembentukan Undang-Undang Pokok Agraria, Isi dan Pelaksanaannya, Djambatan, Jakarta, 2007, hlm. 317
}

berdasarkan pada Putusan Pengadilan Negeri Nomor : 19 /Pdt.G/2015/PN.Mgg tanggal 27 Agustus 2015, yang memutuskan bahwa : "Surat Pernyataan Jual Beli tanah pekarangan tertanggal 24 Juni 1968 antara Ngadijono - Martosarno di hadapan Kepala Desa Tidar adalah Sah dan Berharga. Akan tetapi peralihan hak atas tanah karena jual beli terhadap tanah yang belum didaftarkan juga menimbulkan akibat hukum lainnya yaitu kerugian bagi pihak pemegang hak atas tanah karena tidak adanya jaminan kepastian hukum sesuai dengan tujuan pendaftaran tanah yaitu untuk menjamin kepastian hukum dan kepastian hak atas tanah, yang mana hanya dapat menguasai secara fisik, akan tetapi tidak membuktikan kepemilikan tersebut secara yuridis sebagaimana yang diamanatkan dalam ketentuan Pasal 19 UUPA serta sesuai dengan Peraturan Pemerintah Nomor 24 Tahun 1997 tentang Pendaftaran Tanah.

\section{Perlindungan Hukum Terhadap Pem- beli Hak Atas Tanah Karena Jual Beli Terhadap Tanah Yang Belum Didaft- arkan}

Mewujudkan penjelmaan daripada Ketuhanan Yang Maha Esa, Perikemanusiaan, Kebangsaan, Kerakyatan dan Keadilan Sosial, sebagai asas kerohanian negara dan cita-cita bangsa, seperti yang tercantum di dalam Undang-Undang Dasar, ${ }^{14}$ yang merupakan keharusan dalam melaksanakan ketentuan dalam Pasal 33 ayat (3) Undang-Undang Dasar 1945, yang mewajibkan negara untuk mengatur kepemilikan tanah dan memimpin penggunaannya, hingga semua tanah di seluruh wilayah kedaulatan bangsa dipergunakan untuk sebesar-besarnya kemakmuran rakyat.

Di Indonesia, tanah mempunyai arti yang penting bagi kehidupan rakyat nya. Akan tetapi, dalam kehidupan masyarakat yang ada di wilayah hukum suatu negara, sering terjadi berbagai permasalahan dalam

\footnotetext{
${ }^{14}$ Boedi harsono (I), Op. Cit, hlm. 163
} 
bidang pertanahan dalam hal perolehan tanah khususnya karena jual beli. Negara yang memegang penuh tanggung jawab pada kehidupan rakyat nya harus mampu menyelesaikanpermasalahan-permasalahan yang ditimbulkan akibat jual beli tersebut. Oleh sebab itu, kebijakan yang dibuat dan dikeluarkan oleh negara diharapkan dapat menjadi solusi akan permasalahanpermasalahan yang hidup serta berkembang dalam kehidupan masyarakat tersebut untuk dapat memperoleh perlindungan hukum.

Untuk itu, demi terjaminnya perlindungan hukum oleh negara kepada masyarakat, maka dituangkan dalam ketentuan Pasal 28 D ayat (1) Undang-Undang Dasar 1945 menyebutkan bahwa :

"Setiap orang berhak atas pengakuan, jaminan, perlindungan dan kepastian hukum yang adil serta perlakuan yang sama di hadapan hukum".

Untuk mewujudkan perlindungan hukum kepada masyarakat dalam bidang pertanahan khususnya karena jual beli, berdasarkan ketentuan Pasal 33 ayat (3) Undang-Undang Dasar 1945 yang merupakan landasan kebijakan di bidang pertanahan Indonesia, yang kemudian dijabarkan lebih lanjut dalam UndangUndang Nomor 5 Tahun 1960 tentang Pokok-Pokok Agraria. Untuk itu, segala sesuatu yang berhubungan dengan tanah harus berpedoman dan tunduk pada Undang-Undang Nomor 5 Tahun 1960 tentang Pokok-Pokok Agraria. Landasan filosofis dibentuknya UUPA adalah untuk terwujudnya jaminan kepastian hukum, ketertiban dan perlindungan hukum yang berintikan kebenaran dan keadilan.

Wujud jaminan perlindungan hukum kepada masyarakat dalam hal memperoleh tanah karena perbuatan hukum yakni jual beli adalah oleh pemerintah diadakan pendaftaran tanah di seluruh wilayah
Republik Indonesia menurut ketentuanketentuan yangdiaturperaturanpemerintah, sebagaimana yang diamanatkan dalam Pasal 19 UUPA. Adapun peraturan pemerintah sebagaimana yang dimaksud, merupakan peraturan induk dari pendaftaran tanah adalah Peraturan Pemerintah Nomor 24 Tahun 1997 tentang Pendaftaran Tanah.

Pendaftaran Tanah adalah tugas dan beban pemerintah. Akan tetapi, untuk mensukseskan nya atau keberhasilannya pendaftaran tanah sangat tergantung pada partisipasi aktif dan/atau peranan masyarakat terutama pemegang hak. Sehingga tujuan dari pendaftaran tanah untuk menjamin perlindungan hukum terhadap pemegang hak atas tanah dapat tercapai dengan maksimal.

Namun, kebanyakan masyarakat pada umumnya dalam memperoleh tanah seringkali melalui jual beli di bawah tangan yang secara hukum adat dilakukan di hadapan kepala adat atau kepala desa yang dibuktikan dengan selembar kwitansi dan/atau Surat Pernyataan Jual Beli tanah, dengan dihadiri oleh para pihak yang berkepentingan beserta saksi, atau dengan kata lain jual beli tersebut memenuhi syarat terang dan tunai, tanpa campur tangan Pejabat Pembuat Akta Tanah (PPAT) atau perbuatan hukum tersebut tidak dilakukan di hadapan Pejabat Pembuat Akta Tanah (PPAT) sebagaimana yang diamanatkan dalam Pasal 37 Peraturan Pemerintah Nomor 24 Tahun 1997 tentang Pendaftaran Tanah, dan masih banyak juga ditemukan bahwa tanah yang menjadi objek jual beli tersebut belum didaftarkan. Sehingga menimbulkan akibat yakni peralihan hak atas tanah karena jual beli terhadap tanah yang belum didaftarkan tidak dapat didaftarkan serta tidak dapat memperoleh tanda bukti hak secara yuridis yaitu sertifikat, yang berlaku sebagai alat pembuktian yang kuat, sebagaimana yang dimaksud dalam Pasal 19 UUPA dan Peraturan Pemerintah Nomor 24 Tahun 1997 tentang Pendaftaran Tanah. 
Baiq Henni Paramita Rosandi| Akibat Hukum Jual Beli Hak Atas Tanah Yang Belum Didaftarkan....

Dalam penyelenggaraan pendaftaran tanah perlindungan hukum yang diberikan kepada mereka yang melakukan perbuatan hukum berdasarkan data yang disajikan tergantung pada system publikasi yang digunakan dalam penyelenggaraan pendaftaran tanah. Sistem publikasi pendaftaran tanah terbagi atas dua bagian, yaitu sistem publikasi positif dan sistem publikasi negatif. ${ }^{15}$

Menurut Aartje Tehupeiory, pada dasarnya ada dua system publikasi yang dikenal dalam pendaftaran tanah, yaitu $:^{16}$

1. Sistem publikasi positif, suatu sertifikat tanah yang diberikan itu adalah berlaku sebagai tanda bukti hak atas tanah yang mutlak serta merupakan satu-satunya tanda bukti atas tanah. Memberikan perlindunganyang mutlak, baik terhadap pemegang haknya maupun terhadap pihak ketiga karena keterangan yang tercantum dalam tanda bukti hak tidak dapat diubah. Hasil pendaftaran ini memberikan alat pembuktian yang mutlak sifatnya dan tidak dapat diganggu gugat. Seandainya terjadi kekeliruan, maka walaupun ada keputusan hakim, keterangan dalam tanda bukti hak tetap tidak dapat diubah. Pemerintah lah yang bertanggungjawabataskesalahanpetugas nya, sehingga pihak yang dirugikan akan memperoleh ganti rugi dari pemerintah sejumlah harga tanah. Dengan demikian, orang yang tadinya berhak bisa menjadi tidak berhak.

2. Sistem publikasi negatif, sahnya perbuatan hukum menentukan berpindahnyahakkepadapembeli,danhanya memberikan perlindungan hak kepada pemegang haknya saja (yang berhak), sehingga sistem publikasi ini dikenal dengan asas Nemo Plus Yuris, yakni suatu asas yang menyatakan seseorang tidak

${ }^{15}$ Aartje Tehupeiory, Pentingnya Pendaftaran Tanah Di Indonesia, Raih Asa Sukses Penebar Swadaya Group, Jakarta, 2012, hlm. 26

${ }^{16}$ Ibid, hlm. 27-29 boleh melakukan jual beli kalau dia tidak berwenangatastanahyangbersangkutan. Bahwa orang yang tidak dapat bertindak melebihi kewenangan yang ada padanya, siapa namanya tercantum dalam tanda bukti hak tersebut maka dialah pemegang haknya. Orang lain boleh percaya, boleh tidak percaya atas keterangan yang ada. Bilamana terjadi kesalahan dalam pencatatan, berdasarkan putusan hakim dapat diperbaiki oleh petugas penyelenggarapendaftarantanah.Dengandemikian orang yang berhak tetap terlindungi.

Sistem pendaftaran tanah yang dianut di Indonesia menggunakan sistem negatif yang mengandung unsur-unsur positif, di mana sistem pendaftarannya menggunakan sistem pendaftaran hak, sebagaimana yang tertuang dalam Peraturan Pemerintah Nomor 24 tahun 1997 tentang Pendaftaran Tanah Pasal 32 ayat 1 yang menyatakan :

"Sertifikat merupakan suatu tanda bukti hak yang berlaku sebagai alat pembuktian yang kuat mengenai data fisik dan data yuridis yang termuat di dalamnya, sepanjang data fisik dan data yuridis tersebut sesuai dengan data yang ada dalam surat ukur dan buku tanah hak yang bersangkutan."

Sertifikat merupakan tanda bukti hak yang kuat, dalam arti bahwa selama tidak dapat dibuktikan sebaliknya data fisik dan data yuridis yang tercantum didalamnya harus diterima sebagai data yang benar. Sudah barang tentu data fisik maupun data yuridis yang tercantum dalam sertifikat harus sesuai dengan data yang tercantum dalam buku tanah dan surat ukur yang bersangkutan, karena data itu diambil dari buku tanah dan surat ukur tersebut.

Dalam penjelasan umum juga dijelaskan bahwa, dalam rangka memberikan kepastian hukum kepada pemegang hak atas tanah dalam peraturan pemerintah itu diberikan penegasan mengenai sejauh 
mana kekuatan pembuktian sertifikat, yang dinyatakan sebagai alat pembuktian yang kuat oleh UUPA. Untuk itu diberikan ketentuan bahwa selama belum dibuktikan yang sebaliknya, data fisik dan data yuridis yang dicantumkan dalam sertifikat harus diterima sebagai data yang benar, baik dalam perbuatan hukum sehari-hari maupun dalam sengketa di pengadilan.

Boedi Harsono juga menegaskan bahwa: ${ }^{17}$

"maksud dari sertifikat sebagai alat pembuktian yang kuat adalah selama tidak ada bantahan harus diterima sebagai keterangan yang benar. Tidak ditentukan bahwa sertifikat merupakan satu-satunya pembuktian, jadi masih dimungkinkan adanya alat pembuktian lainya".

Ditegaskan juga dalam ketentuan Peraturan Pemerintah Nomor 24 Tahun 1997 tentang Pendaftaran Tanah Pasal 32 ayat (2) yang menyebutkan :

"Dalam hal atas suatu bidang tanah sudah diterbitkan sertifikat secara sah atas nama orang atau badan hukum yang memperoleh tanah tersebut dengan itikad baik dan secara nyata menguasainya, maka pihak lain yang merasa mempunyai hak atas tanah itu tidak dapat lagi menuntut pelaksanaan hak tersebut apabila dalam waktu 5 (lima) tahun sejak diterbitkannya sertifikat itu telah tidak mengajukan keberatan secara tertulis kepada pemegang sertifikat dan Kepala Kantor Pertanahan yang bersangkutan ataupun tidak mengajukan gugatan ke Pengadilan mengenai penguasaan tanah atau penerbitan sertifikat tersebut."

Pendaftaran tanah yang penyelenggaraannya diperintahkan oleh UUPA tidak menggunakan system publikasi positif,

${ }^{17}$ Boedi Harsono (III), Hukum Agraria Indonesia: Sejarah Pembentukan Undang-Undang Pokok Agraria, Isi dan Pelaksanaannya, Edisi Revisi, Cetakan XII, Djambatan, Jakarta, 2008, hlm. 102 yang kebenaran data yang disajikan dijamin oleh negara, melainkan menggunakan sistem publikasi negatif. Didalam sistem publikasi negatif negara tidak menjamin kebenaran data yang disajikan. Tetapi walaupun demikian tidaklah dimaksudkan untuk menggunakan sistem publikasi negatif secara murni. Hal tersebut tampak dari pernyataan dalam Pasal 19 ayat (2) huruf c UUPA, bahwa surat bukti hak yang diterbitkan berlaku sebagai alat bukti yang kuat dan dalam Pasal 23, 32, dan 38 UUPA bahwa pendaftaran berbagai peristiwa hukum merupakan alat pembuktian yang kuat. Selain itu, dari ketentuan-ketentuan mengenai prosedur pengumpulan, pengolahan, penyimpanan dan penyajian data fisik dan data yuridis serta penerbitan sertifikat dalam Peraturan Pemerintah Nomor 24 Tahun 1997 tentang Pendaftaran Tanah, tampak jelas usaha untuk sejauh mungkin memperoleh dan penyajian data yang benar, karena pendaftaran tanah adalah untuk menjamin kepastian hukum. sehubungan dengan itu diadakan lah ketentuan dalam Pasal 32 ayat (2) Peraturan Pemerintah Nomor 24 Tahun 1997 tentang Pendaftaran Tanah. Ketentuan ini bertujuan, pada satu pihak untuk tetap berpegang pada system publikasi negatif dan pada lain pihak untuk secara seimbang memberikan kepastian hukum kepada pihak, yang dengan itikad baik menguasai sebidang tanah dan didaftar sebagai pemegang hak dalam buku tanah, dengan sertifikat sebagai tanda buktinya, yang menurut UUPA berlaku sebagai alat pembuktian yang kuat.

Dengan demikian, maka makna dari pernyataan bahwa sertifikat merupakan alat pembuktian yang kuat dan bahwa tujuan dari pendaftaran tanah yang diselenggarakan adalah dalam rangka memberikan jaminan kepastian hukum di bidang pertanahan, menjadi tampak dan dirasakan arti praktisnya, sungguhpun sistem publikasi yang digunakan adalah sistem publikasi negatif. Ketentuan tersebut tidak mengu- 
rangi azas pemberian perlindungan yang seimbang baik kepada pihak yang mempunyai tanah dan dikuasai serta digunakan sebagaimana mestinya maupun kepada pihak yang memperoleh dan menguasai nya dengan itikad baik dan dikuatkan dengan pendaftaran tanah yang bersangkutan atas namanya.

Masyarakat pada umumnya terkait dengan peralihan hak atas tanah karena jual beli terhadap tanah yang belum didaftarkan, bila berdasarkan pada teori perlindungan hukum yang dikemukakan oleh Philipus M. Hadjon yakni perlindungan hukum represif, yaitu perlindungan yang arahnya lebih kepada upaya untuk menyelesaikan sengketa, seperti contohnya adalah penyelesaian sengketa di pengadilan. Bilamana perlindungan hukum represif tersebut dikaitkan dengan teori tujuan hukum yang dicetuskan oleh Gustav Radbruch yang menempatkan tujuan keadilan menempati posisi diatas tujuan hukum yang lain.

Keadilan merupakan suatu hasil pengambilan keputusan yang mengandung kebenaran, tidak memihak, dapat dipertanggungjawabkan dan memperlakukan setiap manusia pada kedudukan yang sama di depan hukum. Perwujudan keadilan dapat dilaksanakan dalam ruang lingkup kehidupan masyarakat, bernegara dan kehidupan masyarakat internasional, ditunjukkan melalui sikap dan perbuatan yang tidak berat sebelah dan memberikan sesuatu kepada orang lain yang menjadi haknya.

Maka dengan berdasarkan pada Putusan Pengadilan Negeri Nomor : 19 /Pdt.G/2015/ PN.Mgg tanggal 27 Agustus 2015, yang memutuskan bahwa : "Surat Pernyataan Jual Beli tanah pekarangan tertanggal 24 Juni 1968 antara Ngadijono-Martosarno di hadapan Kepala Desa Tidar adalah Sah dan Berharga. Sehingga dalam hal ini, maka pembeli hak atas tanah karena jual beli terhadap tanah yang belum didaftarkan di mana perbuatan hukum tersebut dilakukan secara itikad baik dengan memenuhi syarat terang dan tunai, dengan demikian pembeli mendapat pengakuan dari masyarakat yang bersangkutan sebagai pemilik yang baru dan akan mendapatkan perlindungan hukum jika di kemudian hari ada gugatan terhadapnya dari pihak yang menganggap jual beli tersebut tidak sah.

Selanjutnya, bila ditinjau dari kelemahan sistem publikasi negatif adalah bahwa namanya tercantum sebagai pemegang hak dalam buku tanah dan sertifikat selalu menghadapi kemungkinan gugatan dari pihak lain yang merasa mempunyai tanah itu, umumnya kelemahan tersebut diatasi dengan menggunakan lembaga acquiitieve verjaring atau adverse possession. Karena hukum tanah kita memakai dasar hukum adat tidak dapat menggunakan lembaga tersebut, karena hukum adat tidak mengenal nya. Tetapi dalam hukum adat terdapat lembaga yang dapat digunakan untuk mengatasi kelemahan sistem publikasi negatif dalam pendaftaran tanah yaitu lembaga rechtsverwerking. Dalam hukum adat jika seseorang selama sekian waktu membiarkan tanahnya dikerjakan, kemudian tanah itu dikerjakan orang lain, yang memperolehnya dengan itikad baik, maka hilanglah haknya untuk menuntut kembali tanah tersebut. Ketentuan didalam UUPA yang menyatakan hapusnya hak atas tanah karena ditelantarkan (Pasal 27, 34, dan 40 UUPA) adalah sesuai dengan lembaga ini.

Sehingga berdasarkan pada hukum adat yang mengenal lembaga rechtsverwerking, makaperlindunganhukum terhadappembeli hak atas tanah yang belum didaftarkan juga berlaku lembaga tersebut. Karena Dalam hukum adat jika seseorang selama sekian waktu membiarkan tanahnya dikerjakan, kemudian tanah itu dikerjakan orang lain, yang memperolehnya dengan itikad baik, maka hilanglah haknya untuk menuntut 
kembali tanah tersebut, ketentuan di dalam UUPA yang menyatakan hapusnya hak atas tanah karena ditelantarkan.

\section{SIMPULAN}

Berdasarkan penjelasan dari uraian pada bagian sebelumnya, maka dapat disimpulkan bahwa :

1. Berdasarkanketentuan Pasal 19 UndangUndang Nomor 5 Tahun 1960 tentang Pokok-Pokok Agraria yang mengharuskan diadakan pendaftaran tanah di seluruh wilayah Republik Indonesia dan Peraturan Pemerintah Nomor 24 Tahun 1997 tentang Pendaftaran Tanah yang merupakan peraturan induk dalam pelaksanaan pendaftaran tanah, seharusnya peralihan hak atas tanah karenajualbeliterhadaptanahyangbelum didaftarkan harus didaftarkan sesuai dengan prosedur yang ditentukan oleh ketentuan hukum yang berlaku.

2. Adapun akibat hukum peralihan hak atas karena jual beli terhadap tanah yang belum didaftarkan adalah sah menurut hukum apabila peralihan hak atas tanah karenajualbeliterhadaptanahyangbelum didaftarkan tersebut sudah memenuhi syarat materil jual beli yaitu "terang dan "Tunai".

3. Wujud perlindungan hukum terhadap pembeli hak atas tanah karena jual beli terhadap tanah yang belum didaftarkan tetapmendapatkan perlindungan hukum apabila yang memperolehnya dengan itikad baik, yaitu berupa perlindungan hukum represif, yaitu perlindungan hukum yang arahnya lebih kepada upaya untuk menyelesaikan sengketa, seperti contohnya adalah penyelesaian sengketa di pengadilan, sehingga berdasarkan yurisprudensi maka hak atas tanah pembeli dapat terlindungi.

\section{DAFTAR PUSTAKA}

Aartje Tehupeiory, 2012, Pentingnya
Pendaftaran Tanah Di Indonesia, Raih Asa Sukses (Penebar Swadaya Group), Jakarta.

Bachtiar Effendie, 1980, Pendaftaran Tanah di Indonesia dan Peraturanperaturan Pelaksanaannya. Alumni. Bandung.

Boedi Harsono, 1999, Hukum Agraria Indonesia: Sejarah Pembentukan Undang-Undang Pokok Agraria, Isi dan Pelaksanaannya, Edisi Revisi, Cetakan VIII, Djambatan, Jakarta.

2007, Hukum Agraria Indonesia, Sejarah Pembentukan UndangUndang Pokok Agraria, Isi dan Pelaksanaannya, Djambatan, Jakarta.

, 2008, Hukum Agraria Indonesia: Sejarah Pembentukan UndangUndang Pokok Agraria, Isi dan Pelaksanaannya, Edisi Revisi, Cetakan XII, Djambatan, Jakarta.

Effendi Perangin, 1986, Hukum Agraria Di Indonesia: Suatu Telaah Dari Sudut pandang Praktisi Hukum, Edisi 1, Cetakan 1, Rajawali, Jakarta.

Harun Al-Rashid, 1986, Sekilas TentangJua 1-Beli Tanah (Berikut PeraturanPeraturanya), Ghalia Indonesia, Jakarta.

J. Kartini Soedjendro, 2001, Perjanjian Peralihan Hak Atas Tanah Yang Berpotensi Konflik, Kanisius, Yogyakarta.

Saleh Adiwinata, 1980, Pengertian Hukum Adat Menurut Undang-Undang Pokok Agraria, Alumni, Bandung.

Amandemen Undang-Undang Dasar Negara Republik Indonesia Tahun 1945.

Undang-Undang Nomor 5 Tahun 1960 tentang Peraturan Dasar PokokPokok Agraria (Lembaran Negara Tahun 1960 Nomor 104 Tahun 1960, Tambahan Lembaran Negara 
Baiq Henni Paramita Rosandi| Akibat Hukum Jual Beli Hak Atas Tanah Yang Belum Didaftarkan....

Nomor 2043).

Kitab Undang-Undang Hukum Perdata.

Peraturan Pemerintah Nomor 24 Tahun 1997 tentang Pendaftaran Tanah (Lembaran Negara Tahun 1997 Nomor 59, Tambahan Lembaran Negara Nomor 3696).

Peraturan Menteri Agraria/Kepala Badan Pertanahan Nasional Nomor 3 Tahun 1997 tentang Ketentuan Pelaksanaan Peraturan Pemerintah Nomor 24 Tahun 1997 tentang Pendaftaran tanah.

Peraturan Pemerintah Nomor 37 Tahun 1998 tentang Peraturan Jabatan Pejabat Pembuat Akta Tanah (Lembaran Negara Nomor 52 Tahun 1998, Tambahan Lembaran Negara Nomor 3746).

Peraturan Kepala Badan Pertanahan Nasional Republik Indonesia Nomor 1 Tahun 2006 tentang Ketentuan Pelaksanaan Peraturan Pemerintah Nomor 37 Tahun 1998 tentang Peraturan jabatan Pejabat Pembuat Akta Tanah.

Putusan Pengadilan Negeri Magelang Nomor : 19/Pdt.G/2015/PN.Mgg tentang Jual Beli Tanah. 